\title{
A jobb kamrai anatómia és funkció korszerú echokardiográfiás vizsgálata: patológiás és fiziológiás eltérések
}

\author{
Lakatos Bálint - Kovács Attila dr. - Tokodi Márton \\ Doronina Alexandra dr. - Merkely Béla dr.
}

Semmelweis Egyetem, Általános Orvostudományi Kar, Városmajori Szív- és Érgyógyászati Klinika, Budapest

\begin{abstract}
A jobb kamra geometriai és funkcionális változásai számos megbetegedésben nagy jelentőséggel bírnak. Mindazonáltal a rutin echokardiográfiás mérések csak korlátozott diagnosztikus és prognosztikus erôvel rendelkeznek. Az olyan modern szívultrahangos technikák, mint a speckle-tracking analízis vagy a $3 \mathrm{D}$ echokardiográfia napjainkban már elérhető és könnyen kivitelezhető módszerek, amelyek a jobb kamra komplex felépítésének és múködésének költséghatékony, noninvazív vizsgálatát teszik lehetôvé. Diagnosztikus értékük és precizitásuk jóval nehezebben hozzáférhetô eljárásokat helyettesíthet. Egyre bővülő irodalmi adatok alapján használatuk a mindennapi klinikumban (jobb kamrai infarktus, pulmonalis hypertensio, arrhythmogen jobb kamrai dysplasia, szívtranszplantáció utáni követés, a sportszív differenciáldiagnosztikája) lényeges segítséget jelenthet. Orv. Hetil., 2016, 157(29), 1139-1146.
\end{abstract}

Kulcsszavak: 3D echokardiográfia, jobb kamra, jobbkamra-funkció

\section{Assessment of the right ventricular anatomy and function by advanced echocardiography: pathological and physiological insights}

\begin{abstract}
Accurate assessment of right ventricular geometry and function is of high clinical importance. However, several limitations have to be taken into consideration if using conventional echocardiographic parameters. Advanced echocardiographic techniques, such as speckle-tracking analysis or 3D echocardiography are reliable and simple tools providing a cost-effective and non-invasive alternative of current modalities used to characterize the right ventricle. There is a growing interest in the diagnostic and prognostic value of these methods regarding pathological (right ventricular infarction, pulmonary hypertension, arrhythmogenic right ventricular dysplasia, follow-up of heart transplantation) and even physiological (athlete's heart) alterations of the right ventricle.
\end{abstract}

Keywords: 3D echocardiography, right ventricle, right ventricular function

Lakatos, B., Kovács, A., Tokodi, M., Doronina, A., Merkely, B. [Assessment of the right ventricular anatomy and function by advanced echocardiography: pathological and physiological insights]. Orv. Hetil., 2016, 157(29), $1139-1146$.

(Beérkezett: 2016. április 4.; elfogadva: 2016. május 11.)

\section{Rövidítések}

ARVD = arrhythmogen jobb kamrai dysplasia $; \mathrm{CX}=$ bal koszorúér körbefutó ága; $\mathrm{EF}=$ ejekciós frakció; $\mathrm{FAC}=$ frakcionális területváltozás; HTX = szívtranszplantáció; LAD = bal koszorúér elülső leszálló ága; MRI = mágneses rezonanciás képalkotás; PET-CT = pozitronemissziós tomográfia-komputertomográfia fúziós képalkotás; PHT = pulmonalis hypertensio; $\mathrm{RCA}=$ jobb koszorúér; TAPSE = tricuspid annular plane systolic excursion
A jobbkamra-funkció és annak változásai hosszú időn át mérsékelt figyelmet kaptak tudományos szempontból, annak ellenére, hogy már Sir William Harvey 1628-as „De Motu Cordis” címú értekezésében is lényeges szerepet tulajdonít a jobb szívfélnek. Mint a szisztémás keringés motorja, a bal kamra volt a vizsgálatok fó tárgya: a kezdeti eredmények alapján a jobb kamra szabad falának kísérletes roncsolása nem járt érdemleges funkcionális 
veszteséggel, így hosszú időn át egyszerü conduit funkciót tulajdonítottak ennek a szívüregnek [1]. Az elmúlt évtizedek kísérletes és klinikai eredményei alapvető változást hoztak ebben a kérdésben, így ma már a jobbkamra-funkció prognosztikus jelentősége számos genetikailag determinált és szerzett betegségben is tudományosan megalapozott.

\section{Jobb kamrai anatómia és funkció}

A négy szívüreg közül a jobb kamra adja a szív elülső falának nagy részét, továbbá közvetlenül a rekeszen fekve az alsó felszín jelentős hányadát is. A bal kamra viszonylag egyszerú kúpszerü formájával ellentétben a jobb kamra összetett felépítésü: anteroposterior hosszmetszetben háromszög alakú, míg a szív keresztmetszetében félhold alakú idomot alkot, részlegesen körülfogva a bal kamrát. A jobb kamra üregét három részre oszthatjuk (1. ábra). A beáramlási („inflow”) régió a háromhegyü billentyưvel, annak ínhúrjaival és szemölcsizmaival; a csúcsi rész a trabekulált izomzattal; illetve a kiáramlási ( outflow”) régió, más néven infundibulum, amit a pulmonalis billentyú választ el a pulmonalis fötörzstől [2]. A bal kamrához viszonyítva kissé magasabb térfogattal és alacsonyabb ejekciós frakcióval rendelkezik fiziológiás körülmények között, továbbá lényegesen alacsonyabb az izomtömege is [3]. Az életkor növekedésével párhuzamosan a térfogat csökkenése és az ejekciós frakció enyhe emelkedése jellemző [4]. A kamrafal izomrostjai subendocardialisan hosszanti, míg subepicardialisan körkörös elrendeződésűek, az utóbbi dominanciájával [2].

A jobb kamra vérellátását döntően a jobb koszorúérből (RCA) kapja. Az esetek egy részében a bal koszorúér körbefutó ága (CX) és az elülső leszálló ág (LAD) is jelentékeny mértékben hozzájárul a jobb szívfél perfúziójához [5], a populáció nagyjából 30\%-ában pedig az infundibulumot közvetlenül az aortából eredő ér látja el [6], így izomzata változatos kollaterális ellátással bír. A bal kamrával ellentétben a jobb kamra falában szignifikáns véráramlás mutatható ki nem csupán diasztoléban, hanem a teljes szívciklus alatt [6], továbbá jóval magasabb oxigénextrakciós rezervvel is bír (nyugalomban mindössze $50 \%$-át vonja ki az artériás vér oxigéntartalmának, szemben a bal kamra 75\%-ával) [7]. Mindezek a tényezők lényeges elemei a jobb kamra ischaemiával szembeni magasabb toleranciájának.

A strukturális eltérésekhez hasonlatosan a funkció tekintetében is lényeges különbségek mutatkoznak a jobb kamra esetében a bal kamrához viszonyítva. A pulmonalis keringés alacsony ellenállásához és a be- és kilégzési munka folytán nagymértékben fluktuáló előterheléshez adaptálódva a jobb kamra alacsony nyomáson változatos térfogatokat képes keringetni a tüdő érrendszerében. A jobb kamrai verőtérfogatot négy különböző mechanizmus hozza létre:

1. A keresztmetszeti átmérő csökkenése a körkörös rostok összehúzódása folytán („fújtató effektus”).
2. A csúcs közeledése a bázishoz a szabad fali hosszanti rostok kontrakciójának eredményeképpen (longitudinális kontrakció).

3. Az infundibulum összehúzódása.

4. A kamraközti sövény ferde rostjainak kontrakciója, ami a jobb kamrában is jelentős hatást fejt ki [8] (2. ábra).

Egészséges egyénekben a longitudinális kontrakció felelős a verôtérfogat nagyjából 80\%-áért [8]. A kontrakció időzítése bemenettől a kimenet felé irányul (perisztaltikus jellegü), ám ez az autonóm idegrendszer befolyására módosulhat.

\section{A jobb kamra echokardiográfiás vizsgálata}

Részlegesen retrosternalis elhelyezkedése folytán a jobb kamra szívultrahangos vizsgálata nehezebb, mint a bal kamráé. A jobb szívfél parasternalis hosszú és rövid tengelyi, valamint csúcsi metszetekből viszonylag jól látótérbe hozható (1. ábra), azonban összetett struktúrájából adódóan a bal kamránál használt térfogatbecslő módszerek nem alkalmazhatók kellő precizitással. Ebből következően a funkció becslése is általában csak közvetett módszerekkel lehetséges: a klinikai gyakorlat leginkább a tricuspidalis anulus M-móddal követett mozgását (TAPSE) és a frakcionális területváltozást (FAC) alkalmazza [3]. Mindkettő technika több ízben bizonyította prognosztikai jelentőségét a jobb szívfél megbetegedéseiben [9-11], míg a FAC elfogadható korrelációt mutatott a szív mágneses rezonanciás (MRI) vizsgálatával meghatározott jobb kamrai ejekciós frakcióval is [12]. Fontos azonban kiemelni, hogy a TAPSE csak a jobb kamrai hosszanti kontrakciót reprezentálja, míg a FACszámítás figyelmen kívül hagyja a jobb kamrai kiáramlási traktus térfogatváltozásait, így nem demonstrálják tökéletesen az aktuális kamrafunkciót. (Ennek ellenére könynyű meghatározhatóságuk folytán számos esetben hasznos ismeretük: a jelenlegi ajánlások szerint a TAPSE $\leq 16$ $\mathrm{mm}$ és/vagy $\mathrm{FAC} \leq 35 \%$ a jobb kamrai diszfunkció jele [3].)

A szöveti Doppler-echokardiográfia, ami a hétköznapokban fóként a bal kamrai diasztolés funkció kvantifikálásában kapott szerepet, a jobb kamra esetében is alkalmazható technika, azonban az ezzel a módszerrel elért eredmények kisebb jelentőségûnek bizonyultak az irodalmi adatokat tekintve. A Doppler-technika ismert szögfüggése és a nehezebben vizualizálható jobb kamra esetében a mért értékek kellő óvatossággal interpretálandók.

Az elmúlt évtized egyik innovatív szívultrahangos módszere a „speckle-tracking” technika, ami egy új, nonvolumetriás eljárás a kamrafunkció mérésére (3. ábra). Egy szoftveres algoritmus segítségével a szívizomzat különféle szövetein szóródó ultrahangnyaláb által keletkező apró fényes foltok („speckle”-ök) képkockáról képkockára követhetők, és relatív elmozdulásuk (strain), illetve elmozdulásuk sebessége (strain rate) számszerü- 


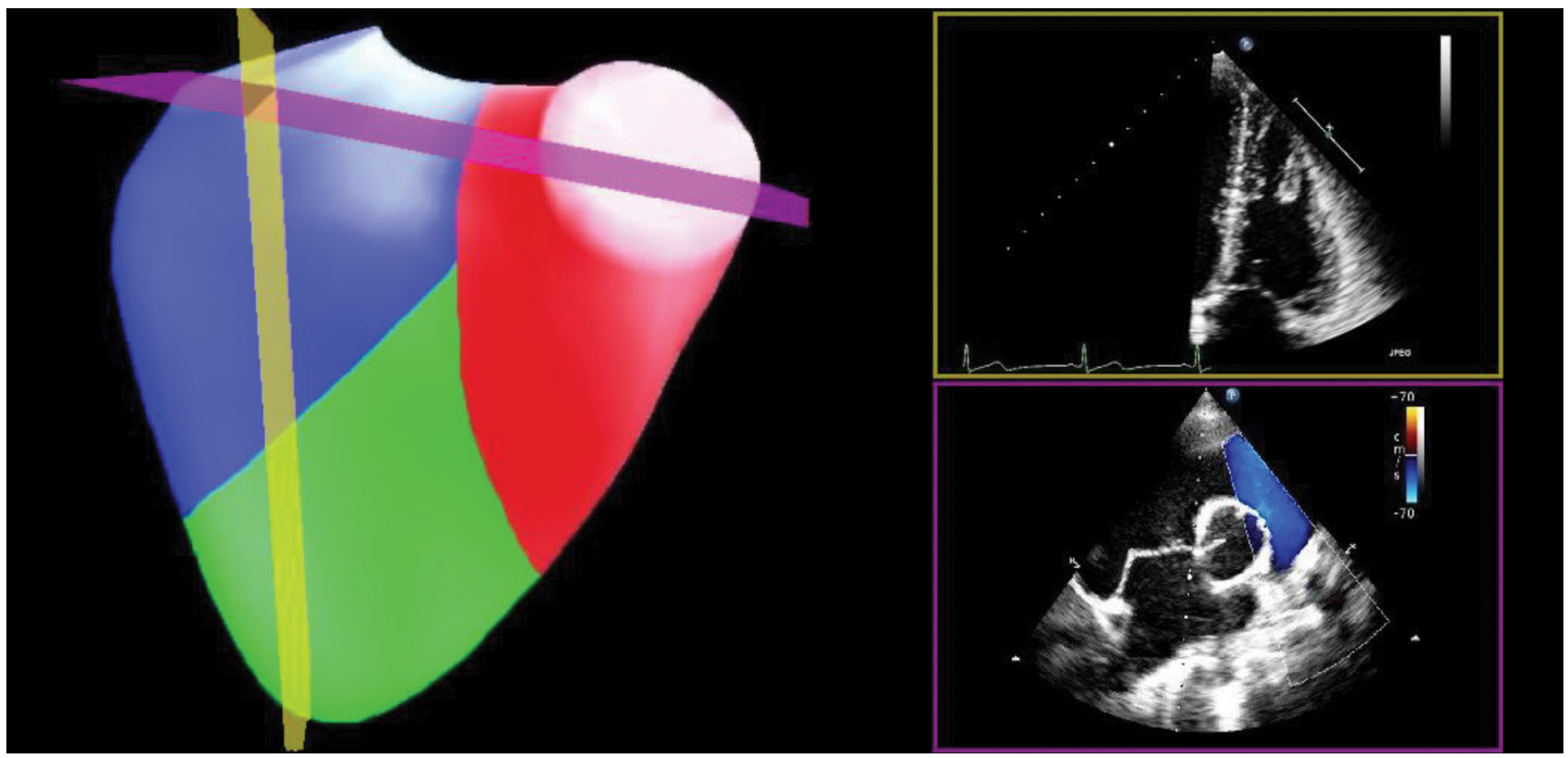

1. ábra

A jobb kamra három részre osztható: beáramlási régió (kék), apicalis harmad (zöld) és kiáramlási régió (piros). A háromdimenziós modellen bejelölt síkok a jobb kamra hagyományos echokardiográfiás vizsgálatának metszési vonalai: apicalis négyüregi metszet (sárga sík, lásd jobbra felül) és parasternalis rövid tengelyi metszet (lila sík, lásd jobbra alul)

síthető, amely érzékeny markere a szívizomzat regionális és globális funkciójának. Az elmozdulás a tér három dimenziójában (longitudinális, circumferentialis, radialis) külön értelmezhető, így a szisztolés funkció mennyiségi aspektusa mellett minőségi szempontból is vizsgálható. Szintén fontos új módszer a 3D echokardiográfia megjelenése, amelyet az új mátrixtranszducerek és a számítástechnika rohamos fejlődése tett végül lehetővé. A transzducer piramis alakú térrészletről készített felvételéből

\section{LONGITUDINÁLIS}

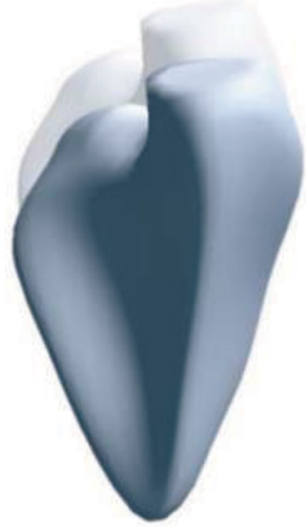

2. ábra
A jobb kamrai térfogatváltozás fó irányai: hosszanti irányú (lon gitudinális) rövidülés a szabad fal belső hosszanti rostjai és a kamraközti sövény által, illetve keresztmetszeti irányú (radialis rövidülés a szabad fal külső körkörös rostjai, az infundibularis és részben a kamraközti sövény által direkt volumetriás mérésekre van lehetőség szoftveres utóelemzéssel, aminek a komplex felépítésű jobb kamrában igen nagy jelentősége van. Precizitása a jobb kamra tekintetében is validált, így reális alternatívája lehet a költségesebb, sokszor nehezen hozzáférhető szív-MRvizsgálatnak [13]. A két echokardiográfiás módszer kombinálható is, kétdimenziós speckle-tracking echokardiográfiás elemzés végezhető 3D felvételből derivált csúcsi négyüregi metszeten [14].

\section{A jobb kamra patológiás eltérései}

\section{Jobb kamrai infarktus}

A jobb kamrai infarktus első irodalmi bemutatása több mint 80 éves [15]. Jellemző módon az RCA proximális okklúziójakor jelentkeznek tünetei, az inferior fali infarktushoz nagyjából az esetek 14-84\%-ában csatlakozik, az állapot diagnosztikus kritériumaitól függően [16]. A jobb kamra diszfunkciója jelentkezhet anterior infarktus esetében is, ilyenkor az infundibularis ág vérátáramlásának és a jobb kamrai funkcióban lényeges szerepet játszó kamraközti sövény ischaemiás károsodása a fó etiológiai tényezők. Izolált jobb kamrai infarktus meglehetősen ritka (az esetek nagyjából 3\%-a), jellegzetesen nondomináns RCA okklúziójakor mutatható ki [5]. A korábban taglalt okok folytán a jobb kamra ischaemiatưrő képessége lényegesebb nagyobb a bal kamrához viszonyítva, így definitív károsodás viszonylag ritkán fordul elő, ám ismert tény, hogy akut állapotban a jobb kamrai diszfunkció megléte igen erős prognosztikus tényező myocardialis infarctusban [17]. 
Az echokardiográfia hasznos eszköz a jobb kamrai infarktus diagnosztikájában. Régóta ismert jelenség a jobb kamrai átmérő növekedése, a falmozgászavarok megjelenése és a paradox septummozgás jobb kamrai infarktusban [18]. A speckle-trackinggel meghatározott jobb kamrai globális longitudinális strain hatékonyabban mutatta ki a jobb kamrai diszfunkciót inferior infarktust elszenvedett betegek körében, mint a konvencionális technikák [19]. A speckle-tracking technika hatékonyan ismeri fel a jobb kamrai myocardialis hegszövet jelenlétét [20], és alkalmas a jobb kamrai funkció posztinfarktusos helyreállásának követésére is [21]. A technika további előnye, hogy regionális funkciómérésre is alkalmas: a falmozgászavar mértéke számszerúsíthetô, amivel a károsodott terület pontosan azonosítható. Így az intervenciós beavatkozás előtt közelítő eredményt kaphatunk arról, hogy a koszorúerek melyik szakaszán található a laesio. A 3D echokardiográfia is hasznos lehet a diagnosztikában, segítségével könnyen meghatározható a jobb kamrai ejekciós frakció, ami $51 \%$ alatti érték esetében 91\%-os szenzitivitással és $80 \%$-os specificitással jelzi a jobb kamrai infarktus meglétét [22].

\section{Pulmonalis hypertensio}

A kisvérköri nyomás emelkedése számos okból létrejöhet [23]. A jobb szívfél következményes átépülése és funkcionális változásai egyrészről diagnosztikus szereppel bírnak, másrészről a betegség prognózisának lényeges faktorai [24]. A krónikus nyomásterhelésre jellegzetes válasz a kamrafal hypertrophiája. Késóbbiekben az üreg dilatációja és progresszív myocardialis diszfunkció alakul ki, és ezek a szerkezeti változások a bal kamra funkcióját is rontják [25] (4. ábra). A jobb szívfél nyomásemelkedése akut jelenség is lehet, döntően pulmonalis embolia következtében, amely számos aspecifikus tünete folytán súlyosan aluldiagnosztizált megbetegedés magas mortalitása ellenére.

A jelenlegi irányelvek kiemelt figyelmet szentelnek a pulmonalis hypertensio diagnosztikájában és követésében a jobb kamrai funkciónak és változásának [26]. A háromhegyű billentyű regurgitatiós sebességének meghatározásával lehetőség nyílik a pulmonalis nyomás egyszerü, noninvazív becslésére [26]. A 3D echokardiográfia segítségével a háromhegyű billentyü bármilyen nézetből ábrázolható, így vizsgálhatóvá válnak szerkezetének specifikus változásai a betegség következtében [27], továbbá a korábbinál pontosabb volumetrikus mérések is véghez vihetők [28], annak figyelembevétele mellett, hogy a 3D echokardiográfiára jellemző enyhe térfogati alulbecslés a pulmonalis hypertensiós betegekre jellemző magasabb volumeneknél kifejezettebb [13].

A pulmonalis embolia szívultrahangos diagnosztikájában a jobb kamrai speckle-tracking analízis és 3D echokardiográfia a konvencionális technikákhoz viszonyítva hatékonyabb diagnosztikus módszernek, továbbá a klinikai kimenetel pontos prediktorának bizonyult [29,
30]. Krónikus thromboemboliás pulmonalis hypertensióban a szabad fali strainérték szoros korrelációt mutatott az invazív módszerrel meghatározott pulmonalis nyomással [31].

\section{Arrhythmogen jobb kamrai dysplasia}

Az arrhythmogen jobb kamrai dysplasia (ARVD) egy viszonylag új klinikai entitás. A sejt-sejt kapcsolatokért felelős különféle desmosomalis proteinek mutációja által okozott változó penetranciájú megbetegedés a jobb (esetenként mindkét oldali) kamrafal zsír- és kötőszövetes infiltrációjával jár, ami kamrai eredetű ritmuszavarokat és progresszív jobb kamrai funkciózavart okoz [32]. A betegség egyre növekvő érdeklődés tárgya, mivel igen fiatal populációt érint (az érintettek huszas-harmincas éveiben jelentkezik), továbbá egyes eredmények szerint a sportolói hirtelen szívhalál egyik legfontosabb etiológiai faktora [33].

A betegség diagnózisa képalkotó és elektrofiziológiai vizsgálatokra épül, és az echokardiográfiának kiemelt szerepe van. A 2010-ben meghatározott Task Force konszenzus [34] 2D echokardiográfiás major és minor kritériumokat fogalmaz meg: a FAC csökkent értéke a betegség egyik funkcionális kórjelzője, ám ez a módszer a korábban taglalt módon figyelmen kívül hagyja a jobb kamrai kiáramlási traktust, ami az ARVD által legkorábban érintett régió és a betegek 100\%-ában tágult [35]. Ennélfogva a kiáramlási pálya tágulata szintén gyanújel, ami a rutin echokardiográfiás vizsgálatnál is megítélhető. A 3D echokardiográfia képes a teljes üregi térfogat ábrázolására, így alkalmas lehet a jobb kamrai térfogatok és ejekciós frakció meghatározására, ami eddig csak szívMRI segítségével volt lehetséges. A módszert ARVD esetében is validálták szív-MRI-vel meghatározott volumenekkel összevetve [36]. A speckle-tracking echokardiográfia szintén része lehet a diagnózis eszköztárának: a jobb kamrai szabad fali strain- és strain rate értékek meghatározása roppant hatékony markere a betegségnek [37], ső́t egyes eredmények szerint a technika alkalmas lehet a tünetmentes mutációhordozók szubklinikus eltéréseinek felismerésére is [38].

\section{Szívtranszplantáció}

Az első sikeres szívtranszplantációt 1967-ben Christian Barnard és csapata hajtotta végre Fokvárosban, ám az igazi áttörést a '80-as évek új immunszuppresszív szereinek (antithymocyta immunglobulin, ciclosporin) használata hozta el. Napjainkban az eljárás a különféle etiológiájú szívelégtelenség szokványos kezelési lehetőségévé vált, évente nagyjából 4000-4500 operációval világszerte [39]. A szívsebészeti beavatkozások általános szövődményei mellett az átültetett szív kiemelt követést igényel a transzplantációra specifikus jelenségek folytán. A posztoperatív időszakban és első hónapban a korai allograftelégtelenség, az első évben az akut graftrejekció és a 


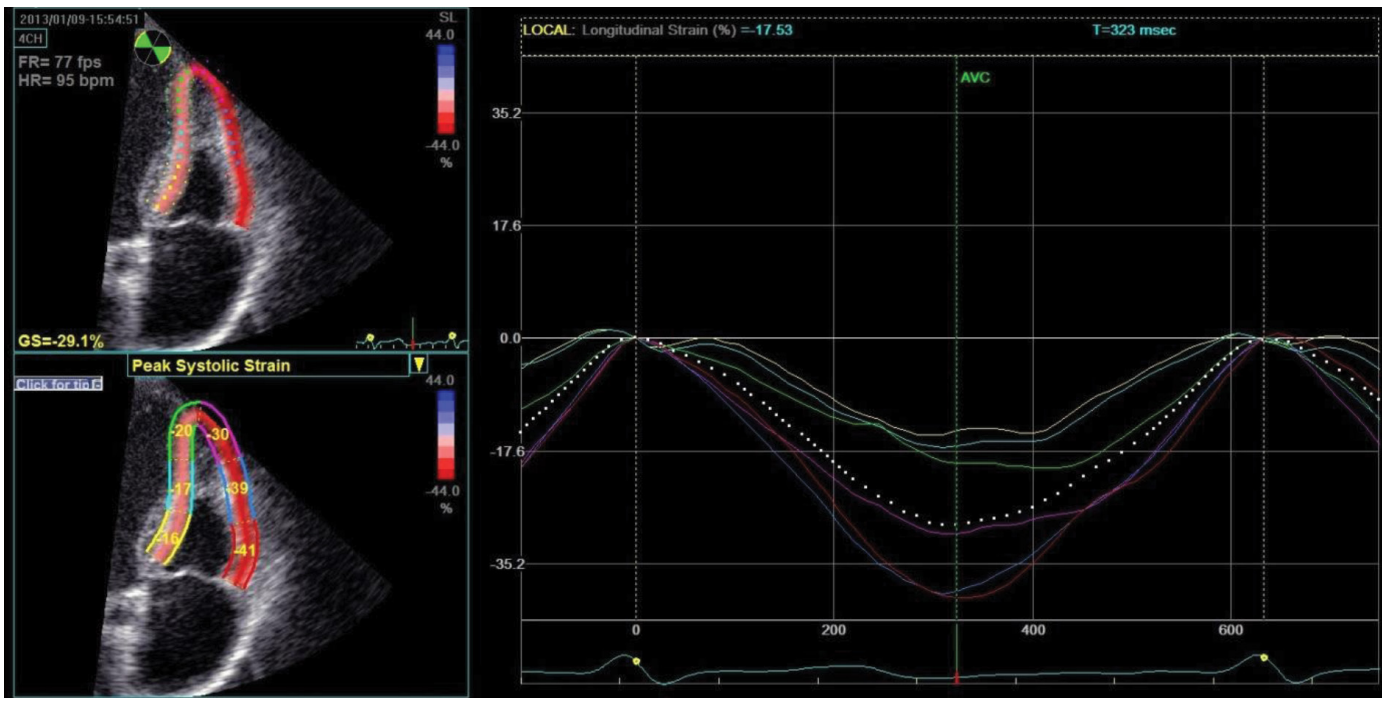

3. ábra

A jobb kamra longitudinális funkció speckle-tracking echokardiográfiás vizsgálata. A szoftver a félautomata módszerrel bejelölt kamrafal mozgását képkockáról képkockára követi. A bal oldalon az egyes fali szegmensek színkóddal vannak elkülönítve, deformációjuk mértéke a jobb oldali diagramon az idő függvényében ábrázolódik

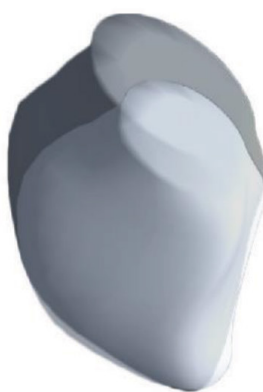

PHT

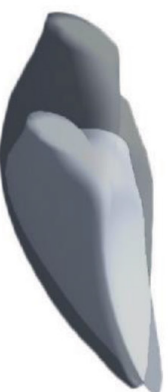

KONTROLL
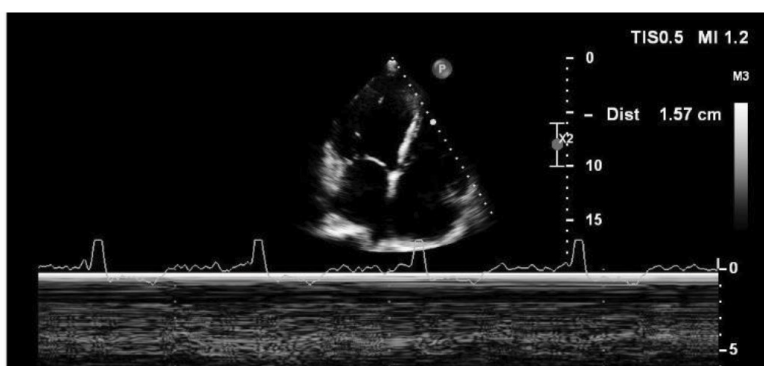

$-10$

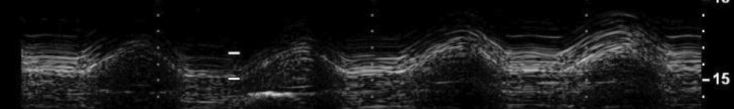

$\frac{1}{75 m m / s}$

Pulmonalis hypertensiós (PHT) beteg háromdimenziós jobbkamra-modellje egy egészséges kontrollal összehasonlítva végdiasztoléban és végszisz toléban. Jól látható a nagymértékú dilatáció (EDV: $233 \mathrm{ml})$, ami csökkent ejekciós frakcióval társul ( $\mathrm{EF}=34 \%)$, ezzel szemben a TAPSE-érték mindössze határérték-csökkenést mutat

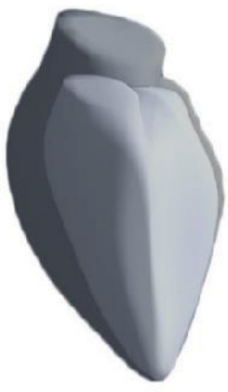

HTX

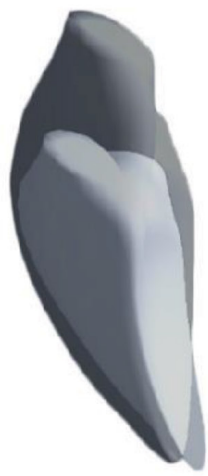

KONTROLI
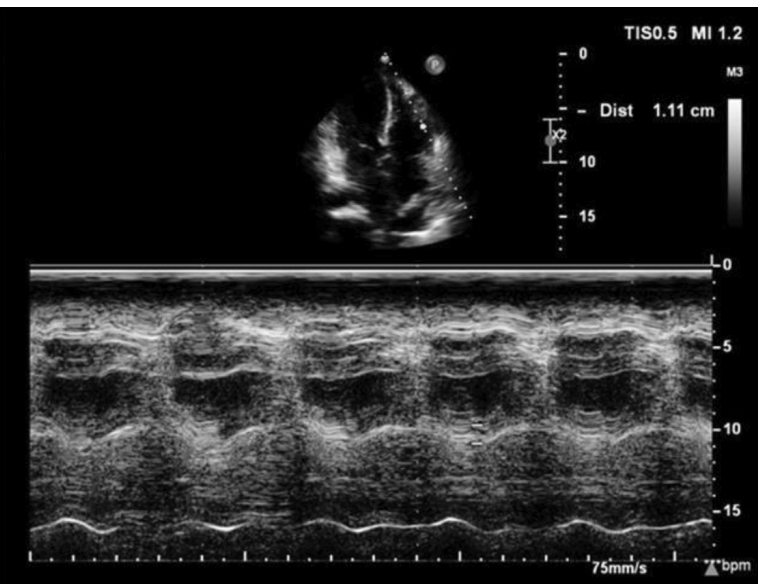

5. ábra $\mid$ Szívtranszplantált beteg (HTX) háromdimenziós jobbkamra-modellje végdiasztoléban és végszisztoléban egészséges kontrollhoz viszonyítva. Jól látható a szívátültetett beteg kamrájának a fiziológiás állapottól eltérő mozgásmintája: a döntően longitudinális irányú kontrakciót a radialis irányú térfogatcsökkenés dominanciája váltja fel. Ugyanezen beteg TAPSE-értékének mérése, ami jelentősen csökkent jobbkamra-funkcióra utal (TAPSE = $11 \mathrm{~mm})$, amelyet a 3D ultrahanggal meghatározott ejekciós frakció nem igazol $(\mathrm{EF}=52 \%)$ 
többéves túlélésnél jelentkező krónikus graftrejekció/ allograft-vasculopathia felismerése, illetve progressziójának követése döntően képalkotó vizsgálatokra támaszkodik, amelynek protokollját nemzetközi irányelvek rögzítik [40].

A jobbkamra-funkcióval kapcsolatos komplikációk felelősek az intraoperatív és posztoperatív periódus szövődményeinek 50\%-áért, illetve a halálozás 19\%-áért [39]. Jellemző lelet a jobb kamrai szabad fal diffúz falmozgászavara és csökkent TAPSE-érték megtartott balkamra-funkció mellett [40]. A komplikációmentes beavatkozások esetén a tartósan csökkent és lassú javulást mutató TAPSE-érték általános jelenség megtartott jobb kamrai ejekciós frakció mellett [41]. Ez a klinikai kép egyéb szívsebészeti beavatkozásoknál is jelen van, és feltehetően multifaktoriális eredetű [42]. A jobb kamrai longitudinális funkció csökkenése megtartott kamrafunkció mellett speckle-tracking analízissel is észlelhető [43]. Mindezek az eredmények felhívják a figyelmet arra a kevéssé feltárt kérdéskörre, hogy a komplex múködésú jobb kamra kontrakciós mintázata egyes állapotokban minőségileg és nem mennyiségileg módosulhat, illetve ennélfogva a TAPSE, mint rutin funkcionális paraméter szívsebészeti beavatkozásokat követően, így szívtranszplantáció esetében sem ideális marker (5. ábra). A 3D echokardiográfiával meghatározott jobb kamrai térfogatok és a speckle-tracking analízis kontraktilitásra utaló paraméterei a páciensek megbízhatóbb követését biztosíthatják.

\section{Sportszin}

A rendszeres fizikai terheléssel kapcsolatos szív- és érrendszeri változásokat már több mint 100 éve vizsgálja az orvostudomány. A sporttevékenységgel kapcsolatos hemodinamikai változások jellegzetes átépülést indukálnak: a jobb kamra tekintetében fóként a dinamikus terhelésû sportágak (például hosszútávfutás, kerékpározás) az üreg dilatációja mellett a kamrafal hypertrophiáját serkentik a bal kamrához hasonlatosan, bár kevésbé kifejezett mértékben [44]. A funkció tekintetében ismert differenciáldiagnosztikai problémát jelent a normáltartomány alsó felében lévő vagy enyhén csökkent ejekciós frakció [45]. Speckle-tracking echokardiográfiával csökkent nyugalmi globális longitudinális strain mérhető [46]. Mindezek a jelenségek fóként a jobb kamra geometriai változásainak tudhatók be, amelyet a terhelés hatására rendeződő, sőt szupranormális szintet elérő szisztolés funkció igazol [46]. Mindemellett a sportszív és egyes patológiás állapotok elkülönítése nem ritka klinikai probléma a két entitás közös pontjai (mint például a dilatáció, hypertrophia, csökkent nyugalmi funkció) miatt, és ennek a „szürke zónának” a diagnosztikája máig nem tökéletesen megoldott.

Az echokardiográfiának lényeges szerepe van a rutin szürési eljárás alapján fokozott kockázatúnak minősülő sportoló kivizsgálásában [47]. A súlyos szívbillentyúmúködési zavarok és pulmonalis eredetú jobbkamrakárosodás elkülönítése a sportszív morfológiai és funkcionális sajátosságaitól jellemzően nem okoz nehézséget, a legfontosabb problémának a jobb kamrai arrhythmogen dysplasia (ARVD) felismerése tekinthetô, amelynek diagnosztikájával kapcsolatban utalok a korábbi bekezdésekre. Egyes bizonyítékok alapján a rendszeres fizikai terhelés növeli az ARVD-ért felelős mutációk penetranciáját [48], így a pozitív családi anamnézis és a minor tünetek észlelése is kiemelt alarmírozó jel élsportolók esetén.

\section{Az új echokardiográfiás módszerek jövőbeli irányai}

A 3D echokardiográfia és speckle-tracking technika, túllépve korábbi státuszukon, napjaink klinikumának részévé válhatnak. A jelenlegi szakmai irányelvek már mindkét módszer esetében meghatározzák a referenciaértékeket [3]. A jobb kamrai speckle-tracking analízissel meghatározott strainértékek fiziológiás tartományával kapcsolatban még nem állnak rendelkezésre multicentrikus tanulmányok, így további vizsgálatok és metaanalízisek szükségesek a teljes klinikai validációhoz. A számítási teljesítmény progresszív növekedése és szoftveres fejlesztések a képfeldolgozás folyamatos fejlődését segítik, amelyek a képminőség és az endocardium-üreg határ pontosabb felismerését és követését teszik lehetővé, ami mindkét módszer esetében precízebb adatokat és a jelenlegi, rutin szívultrahangos vizsgálatnál hosszabb vizsgálati idő csökkenését eredményezik. A 3D echokardiográfia kiváló időbeli felbontásának és a szív-MRI pontos térbeli felbontóképességének kombinálása (a PET-CT vizsgálathoz hasonló fúziós képalkotás) a szív morfológiai és funkcionális státuszának kiemelkedően pontos vizsgálati módszere lehet.

\section{Következtetések}

A jobb kamra geometriai és funkcionális változásai számos megbetegedésben nagy jelentőséggel bírnak, ám a rutin echokardiográfiás technikákkal csak korlátozottan mérhetők fel. A 3D echokardiográfia és a speckle-tracking analízis napjainkban már megbízható és könnyen elvégezhető módszerek, amelyek a jobb kamra komplex felépítésének és múködésének alacsony költségú, noninvazív vizsgálatát teszik lehetővé.

Anyagi támogatás: A közlemény megírása anyagi támogatásban nem részesült.

Szerzői munkamegosztás: L. B.: Irodalomkutatás, a kézirat szövegezése, képszerkesztés. T. M.: Irodalomkutatás, képszerkesztés. D. A.: Irodalomkutatás, szakmai ta- 
nácsok. K. A., M. B.: Szakmai és szerkesztési tanácsok, lektorálás. A cikk végleges változatát valamennyi szerző elolvasta és jóváhagyta.

Érdekeltségek: A szerzőknek nincsenek érdekeltségeik.

\section{Irodalom}

[1] Starr, I., Jeffers, W. A., Meade, R. H.: The absence of conspicuous increments of venous pressure after severe damage to the right ventricle of the dog, with a discussion of the relation between clinical congestive failure and heart disease. Am. Heart J., 1943, 26(3), 291-301.

[2] Ho, S. Y., Nihoyannopoulos, P.: Anatomy, echocardiography, and normal right ventricular dimensions. Heart, 2006, 92(Suppl. 1), i2-il3.

[3] Lang, R. M., Badano, L. P., Mor-Avi, V., et al.: Recommendations for cardiac chamber quantification by echocardiography in adults: an update from the American Society of Echocardiography and the European Association of Cardiovascular Imaging. J. Am. Soc. Echocardiogr., 2015, 28(1), 1-39.el4.

[4] Kawut, S. M., Lima, J. A., Barr, R. G., et al.: Sex and race differences in right ventricular structure and function: the multi-ethnic study of atherosclerosis-right ventricle study. Circulation, 2011, 123(22), 2542-2551.

[5] Andersen, H. R., Falk, E., Nielsen, D.: Right ventricular infarction: frequency, size and topography in coronary heart disease: a prospective study comprising 107 consecutive autopsies from a coronary care unit. J. Am. Coll. Cardiol., 1987, 10(6), 12231232.

[6] Haddad, F., Hunt, S. A., Rosenthal, D. N., et al.: Right ventricular function in cardiovascular disease, part I: Anatomy, physiology, aging, and functional assessment of the right ventricle. Circulation, 2008, 117(11), 1436-1448.

[7] Zong, P., Tune, J. D., Downey, H. F.: Mechanisms of oxygen demand/supply balance in the right ventricle. Exp. Biol. Med. (Maywood), 2005, 230(8), 507-519.

[8] Buckberg, G., Hoffman, J. I.: Right ventricular architecture responsible for mechanical performance: unifying role of ventricular septum. J. Thorac. Cardiovasc. Surg., 2014, 148(6), 31663171.e4.

[9] Kjaergaard, J., Akkan, D., Iversen, K. K., et al.: Right ventricular dysfunction as an independent predictor of short- and long-term mortality in patients with heart failure. Eur. J. Heart Fail., 2007, 9(6-7), 610-616.

[10] Guazzi, M., Bandera, F., Pelissero, G., et al.: Tricuspid annular plane systolic excursion and pulmonary arterial systolic pressure relationship in heart failure: an index of right ventricular contractile function and prognosis. Am. J. Physiol. Heart Circ. Physiol., 2013, 305(9), H1373-H1381.

[11] Kammerlander, A. A., Marzluf, B. A., Graf, A., et al.: Right ventricular dysfunction, but not tricuspid regurgitation, is associated with outcome late after left heart valve procedure. J. Am. Coll. Cardiol., 2014, 64(24), 2633-2642.

[12] Anavekar, N. S., Gerson, D., Skali, H., et al.: Two-dimensional assessment of right ventricular function: an echocardiographicMRI correlative study. Echocardiography, 2007, 24(5), 452456.

[13] Shimada, Y. J., Shiota, M., Siegel, R. J., et al.: Accuracy of right ventricular volumes and function determined by three-dimensional echocardiography in comparison with magnetic resonance imaging: a meta-analysis study. J. Am. Soc. Echocardiogr., 2010, 23(9), 943-953.

[14] Nemes, A., Kalapos, A., Domsik, P., et al.: Three-dimensional speckle-tracking echocardiography - a further step in non-invasive three-dimensional cardiac imaging. [Háromdimenziós speckle-tracking echocardiográfia - egy újabb lépés a noninvaziv háromdimenziós kardiális képalkotásban.] Orv. Hetil., 2012, 153(40), 1570-1577. [Hungarian]

[15] Sanders, A. O.: Coronary thrombosis with complete heart-block and relative ventricular tachycardia. A case report. Am. Heart J., $1931,6(6), 820-823$.

[16] Kinch, J. W., Ryan, T. J.: Right ventricular infarction. N. Engl. J. Med., 1994, 330(17), 1211-1217.

[17] Zehender, M., Kasper, W., Kauder, E., et al.: Right ventricular infarction as an independent predictor of prognosis after acute inferior myocardial infarction. N. Engl. J. Med., 1993, 328(14), 981-988.

[18] Jugdutt, B. I., Sussex, B. A., Sivaram, C. A., et al.: Right ventricular infarction: two-dimensional echocardiographic evaluation. Am. Heart J., 1984, 107(3), 505-518.

[19] Lemarié, J., Huttin, O., Girerd, N., et al.: Usefulness of speckletracking imaging for right ventricular assessment after acute myocardial infarction: A magnetic resonance imaging/echocardiographic comparison within the relation between aldosterone and cardiac remodeling after myocardial infarction study. J. Am. Soc. Echocardiogr., 2015, 28(7), 818-827.e4.

[20] Hutyra, M., Skála, T., Horák, D., et al.: Echocardiographic assessment of global longitudinal right ventricular function in patients with an acute inferior ST elevation myocardial infarction and proximal right coronary artery occlusion. Int. J. Cardiovasc. Imaging, 2015, 31(3), 497-507.

[21] Huttin, O., Lemarié, J., Di Meglio, M., et al.: Assessment of right ventricular functional recovery after acute myocardial infarction by $2 \mathrm{D}$ speckle-tracking echocardiography. Int. J. Cardiovasc. Imaging, 2015, 31(3), 537-545.

[22] Kidawa, M., Chizyński, K., Zielińska, M., et al.: Real-time 3D echocardiography and tissue Doppler echocardiography in the assessment of right ventricle systolic function in patients with right ventricular myocardial infarction. Eur. Heart J. Cardiovasc. Imaging, 2013, 14(10), 1002-1009.

[23] Simonneau, G., Gatzoulis, M. A., Adatia, I., et al.: Updated clinical classification of pulmonary hypertension. J. Am. Coll. Cardiol., 2013, 62(25 Suppl.), D34-D41.

[24] Sandoval, J., Banerle, O., Palomar, A., et al.: Survival in primary pulmonary hypertension. Validation of a prognostic equation. Circulation, 1994, 89(4), 1733-1744.

[25] Badano, L. P., Ginghina, C., Easaw, J., et al.: Right ventricle in pulmonary arterial hypertension: haemodynamics, structural changes, imaging, and proposal of a study protocol aimed to assess remodelling and treatment effects. Eur. J. Echocardiogr., 2010, 11(1), 27-37.

[26] Galiè, N., Humbert, M., Vachiery, J. L., et al.: 2015 ESC/ERS Guidelines for the diagnosis and treatment of pulmonary hypertension: The Joint Task Force for the Diagnosis and Treatment of Pulmonary Hypertension of the European Society of Cardiology (ESC) and the European Respiratory Society (ERS): Endorsed by: Association for European Paediatric and Congenital Cardiology (AEPC), International Society for Heart and Lung Transplantation (ISHLT). Eur. Heart J., 2016, 37(1), 67-119.

[27] Grapsa, J., O’Regan, D. P., Pavlopoulos, H., et al.: Right ventricular remodelling in pulmonary arterial hypertension with threedimensional echocardiography: comparison with cardiac magnetic resonance imaging. Eur. J. Echocardiogr., 2010, 11(1), 64-73.

[28] Amaki, M., Nakatani, S., Kanzaki, H., et al.: Usefulness of three-dimensional echocardiography in assessing right ventricular function in patients with primary pulmonary hypertension. Hypertens. Res., 2009, 32(5), 419-422.

[29] Wright, L., Dwyer, N., Power, J., et al.: Right ventricular systolic function responses to acute and chronic pulmonary hypertension: assessment with myocardial deformation. J. Am. Soc. Echocardiogr., 2016, 29(3), 259-266. 
[30] Stergiopoulos, K., Babrainy, S., Strachan, P., et al.: Right ventricular strain rate predicts clinical outcomes in patients with acute pulmonary embolism. Acute Card. Care, 2011, 13(3), 181-188.

[31] Shiino, K., Sugimoto, K., Yamada, A., et al.: Usefulness of right ventricular basal free wall strain by two-dimensional speckle tracking echocardiography in patients with chronic thromboembolic pulmonary hypertension. Int. Heart J., 2015, 56(1), 100104.

[32] Marcus, F. I., Fontaine, G. H., Guiraudon, G., et al.: Right ventricular dysplasia: a report of 24 adult cases. Circulation, 1982, 65(2), 384-398.

[33] Thiene, G., Nava, A., Corrado, D., et al.: Right ventricular cardiomyopathy and sudden death in young people. N. Engl. J. Med., 1988, 318(3), 129-133.

[34] Marcus, F. I., McKenna, W. J., Sherrill, D., et al.: Diagnosis of arrhythmogenic right ventricular cardiomyopathy/dysplasia: proposed modification of the Task Force criteria. Circulation, 2010, 121(13), 1533-1541.

[35] Yoerger, D. M., Marcus, F., Sherrill, D., et al.: Echocardiographic findings in patients meeting task force criteria for arrhythmogenic right ventricular dysplasia: new insights from the Multidisciplinary Study of Right Ventricular Dysplasia. J. Am. Coll. Cardiol., 2005, 45(6), 860-865.

[36] Prakasa, K. R., Dalal, D., Wang, J., et al.: Feasibility and variability of three dimensional echocardiography in arrhythmogenic right ventricular dysplasia/cardiomyopathy. Am. J. Cardiol., 2006, 97(5), 703-709.

[37] Teske, A. J., Cox, M. G., De Boeck, B. W., et al.: Echocardiographic tissue deformation imaging quantifies abnormal regional right ventricular function in arrhythmogenic right ventricular dysplasia/cardiomyopathy. J. Am. Soc. Echocardiogr., 2009, 22(8), 920-927

[38] Teske, A. J., Cox, M. G., Te Riele, A. S., et al.: Early detection of regional functional abnormalities in asymptomatic ARVD/C gene carriers. J. Am. Soc. Echocardiogr., 2012, 25(9), $997-$ 1006

[39] Lund, L. H., Edwards, L. B., Kucheryavaya, A. Ү., et al.: The registry of the International Society for Heart and Lung Transplantation: Thirty-second official adult heart transplantation report - 2015; Focus theme: early graft failure. J. Heart Lung Transplant., 2015, 34(10), 1244-1254.

[40] Badano, L. P., Miglioranza, M. H., Edvardsen, T., et al.: European Association of Cardiovascular Imaging/Cardiovascular Imaging Department of the Brazilian Society of Cardiology recommendations for the use of cardiac imaging to assess and follow patients after heart transplantation. Eur. Heart J. Cardiovasc. Imaging, 2015, 16(9), 919-948.

[41] Mastouri, R., Batres, $\Upsilon$., Lenet, A., et al.: Frequency, time course, and possible causes of right ventricular systolic dysfunction after cardiac transplantation: a single center experience. Echocardiography, 2013, 30(1), 9-16.

[42] Tamborini, G., Muratori, M., Brusoni, D., et al.: Is right ventricular systolic function reduced after cardiac surgery? A two- and three-dimensional echocardiographic study. Eur. J. Echocardiogr., 2009, 10(5), 630-634.

[43] Moñivas Palomero, V., Mingo Santos, S., Goirigolzarri Artaza, J., et al.: Two-dimensional speckle tracking echocardiography in heart transplant patients: two-year follow-up of right and left ventricular function. Echocardiography, 2016, 33(5), 703-713.

[44] Major, Z., Csajági, E., Kneffel, Z., et al.: Comparison of left and right ventricular adaptation in endurance-trained male athletes. Acta Physiol. Hung., 2015, 102(1), 23-33.

[45] Perseghin, G., De Cobelli, F., Esposito, A., et al.: Effect of the sporting discipline on the right and left ventricular morphology and function of elite male track runners: a magnetic resonance imaging and phosphorus 31 spectroscopy study. Am. Heart J., 2007, 154(5), 937-942.

[46] La Gerche, A., Burns, A. T., D'Hooge, J., et al.: Exercise strain rate imaging demonstrates normal right ventricular contractile reserve and clarifies ambiguous resting measures in endurance athletes. J. Am. Soc. Echocardiogr., 2012, 25(3), 253-262.el.

[47] Corrado, D., Pelliccia, A., Bjørnstad, H. H., et al.: Cardiovascular pre-participation screening of young competitive athletes for prevention of sudden death: proposal for a common European protocol. Consensus Statement of the Study Group of Sport Cardiology of the Working Group of Cardiac Rehabilitation and Exercise Physiology and the Working Group of Myocardial and Pericardial Diseases of the European Society of Cardiology. Eur. Heart J., 2005, 26(5), 516-524.

[48] James, C. A., Bhonsale, A., Tichnell, C., et al.: Exercise increases age-related penetrance and arrhythmic risk in arrhythmogenic right ventricular dysplasia/cardiomyopathy-associated desmosomal mutation carriers. J. Am. Coll. Cardiol., 2013, 62(14), $1290-1297$.
(Merkely Béla dr.,

Budapest, Városmajor utca 68., 1122 e-mail: merkely.study@gmail.com)

Az Orvosi Hetilap egyes számai megvásárolhatók a Mediprint Orvosi Könyvesboltban.

Cím: Budapest V., Múzeum krt. 17. - Telefon: 317-4948 